\title{
ASSESSMENT OF METALS CONTAMINATION AND ECOLOGICAL RISK IN AIT AMMAR ABANDONED IRON MINE SOIL, MOROCCO
}

\author{
MOHAMED NOURI ${ }^{*}$, ABD EL MAJID HADDIOUI
}

Laboratory of Management and Valorization of Natural Resources, University of Sultan Moulay Slimane, Faculty of Science and Techniques, P.O. 523, Beni-Mellal 23000, Morocco; e-mail: mohamednouri35@gmail.com

*Author for correspondence

\begin{abstract}
Nouri M., Haddioui A.: Assessment of metals contamination and ecological risk in ait Ammar abandoned iron mine soil, Morocco. Ekológia (Bratislava), Vol. 35, No. 1, p. 32-49, 2016.

The present study is an attempt to assess the pollution intensity and corresponding ecological risk of phosphorus and metals including $\mathrm{Cd}, \mathrm{Cr}, \mathrm{Cu}, \mathrm{Zn}, \mathrm{Pb}$ and $\mathrm{Fe}$ using various indices like geoaccumulation index, enrichment factor, pollution and ecological risk index. In all, 20 surface soil samples were collected from the Ait Ammar iron mine of Oued Zem city, province of Khouribga, in central Morocco. The concentrations of heavy metals in soil samples were used to assess their potential ecological risks. According to the results of potential ecological risk index $\left(\mathrm{R}_{\mathrm{I}}\right)$, pollution index (PI), geo-accumulation index $\left(\mathrm{I}_{\text {gee }}\right)$, enrichment factor $(\mathrm{EF})$, potential contamination index $(\mathrm{Cp})$, contaminant factor $(\mathrm{Cf})$ and degree of contamination $(\mathrm{Cd})$, based on the averages, considerable pollution of metals in soils of study area was observed. The consequence of the correlation matrix and principal component analysis (PCA) indicated that $\mathrm{Fe}, \mathrm{Cu}, \mathrm{Zn}, \mathrm{Cr}$ and $\mathrm{P}$ mainly originated from natural sources and $\mathrm{Cd}$ and $\mathrm{Pb}$ are mostly derived from anthropogenic sources. The results showed that these metals in soil were ranked by severity of ecological risk as $\mathrm{Pb}>\mathrm{Cd}$ $>\mathrm{Cu}>\mathrm{Cr}>\mathrm{Zn}$, based on their single-element indexes. In view of the potential ecological risk $\left(\mathrm{R}_{\mathrm{I}}\right)$, soils from all soil samples showed a potential ecological risk. These results will provide basic information for the improvement of soil environment management and heavy metal pollution prevention in Ait Ammar.
\end{abstract}

Key words: iron mine, soil pollution, metal, potential ecological risk.

\section{Introduction}

Heavy metal contamination of soils concern several scientists because of the potential toxicity of metals (Homa et al., 2003). Anthropogenic actions related to industrialization are central sources of heavy metals to soils (Stafilov et al., 2010). In addition, heavy metals can be transported long distances via atmospheric particulates after their liberation into the environment, which can expand the area touched by metal contamination (Wu et al., 2010); a portion of metals in the atmosphere may be transferred to soils by atmospheric deposition (Lu et al., 2010). Consequently, soils, especially those in the vicinity of industrial sites, are important sinks for heavy metals. 
Soil is a dynamic natural resource for the survival of human life and due to its complex matrix is the principal receiver of the persistent contaminants such as heavy metals (Luo et al., 2007). Every soil comprises some natural quantities of heavy metals, at concentrations called backgrounds. The magnitude of a metal's background depends upon the composition of the parent rock material from which the soil was derived (Scazzola et al., 2003). Human activities that add waste material to the soils also influence its metal concentration (Pastor, Hernandez, 2012).

The results of the ecological risk assessment can reveal the possibility for soil to be contaminated, and even for the ecology to be harmed by concerned heavy metals (Fairbrother et al., 2007), so these results were usually utilized to serve as a guide for all US Environmental Protection Agency (EPA) programmes and regional offices to supplement or update the policies, practices and guidance. Consequently, such researches have got much attention from investigators over the world, and a great development has been made (Posthuma et al., 2008). Meanwhile, more and more works and practices showed that, such results from the risk assessment have little capability to reveal the real degree of their potential toxic effects totally, especially, no capability to show whether the potential toxic effect is coming into an observed harm of ecology and its degree. So, based on the results, relative strategies and methods were taken to control the risk and even their practices usually were not operated in time. Therefore, a great harm of ecology would have happened at the end. Obviously, in order to obviate an ecology system to be harmful, it is important to do an assessment of ecological risk; meanwhile, it is necessary to do primary empirical researches too.

Understanding the contamination characteristics of heavy metals in soils and identifying their environmental exposure risks not only are the basic preconditions for soil pollution prevention, but also provide important information for making decisions for remediation of contaminated soils. The objectives of this study are to identify the potential sources of phosphorus and metals and to evaluate the pollution level of soil metals in Ait Ammar iron mine area (Oued Zem, Morocco).

\section{Material and methods}

\section{Soil samples collection and analysis}

In 19 July 2010, surface soil $(0$ to $20 \mathrm{~cm})$ was collected in the Ait Ammar iron mine ( $\left.33^{\circ} 04^{\prime} \mathrm{N} ; 6^{\circ} 38^{\prime} \mathrm{W}\right)$, which is placed in the khouribga Province, Morocco. The region's climate is arid to semi-arid (Nouri et al., 2014) and the area is rich with natural phosphate. Four transects (T1-T4) were selected along the direction of iron mine. Five soil elements from the mine were picked in each transect, forming five rounds (R) e.g. R1 contained T.1.1, T.2.1, T.3.1 and T.4.1. Points on each transect were preferred based on distance, with the most distance point being at 300 to 600 $\mathrm{m}$ from the corresponding first point (Fig. 1). Each sample was composed of five subsamples collected around the point and already pooled in the field. Soils at Ait Ammar are highly disturbed, varying in texture and color (brown to black). In addition, one reference site (REF) ( $\left.6^{\circ} 34^{\prime} 2^{\prime \prime} \mathrm{W} ; 32^{\circ} 49^{\prime} 34^{\prime \prime} \mathrm{N}\right)$, utilized as a fallow and located about $27 \mathrm{~km}$ south of the mining site, was identified. Soil from five spots at REF was mixed and treated as the transect samples, forming a total of 21 samples. The 21 samples ( 4 transects $\times 5$ units + reference sample) were carried to the laboratory at $4{ }^{\circ} \mathrm{C}$. A portion of each sample was ground to $2 \mathrm{~mm}$ for physico-chemical analyses.

The concentrations of phosphorus and metals $(\mathrm{Cd}, \mathrm{Pb}, \mathrm{Cr}, \mathrm{Cu}, \mathrm{Zn}$, and $\mathrm{Fe})$ in soil were measured after their digestion in $\mathrm{HNO}_{3}, \mathrm{HF}$ and $\mathrm{HCl}$ (Nouri et al., 2014). The concentrations of the metals were determined by inductively coupled plasma-atomic emission spectrometry (ICP-AES, Jobin Yvon ULTIMA 2) (The National Centre for Scientific and Technical Research (NCSTR), Rabat, Morocco). 


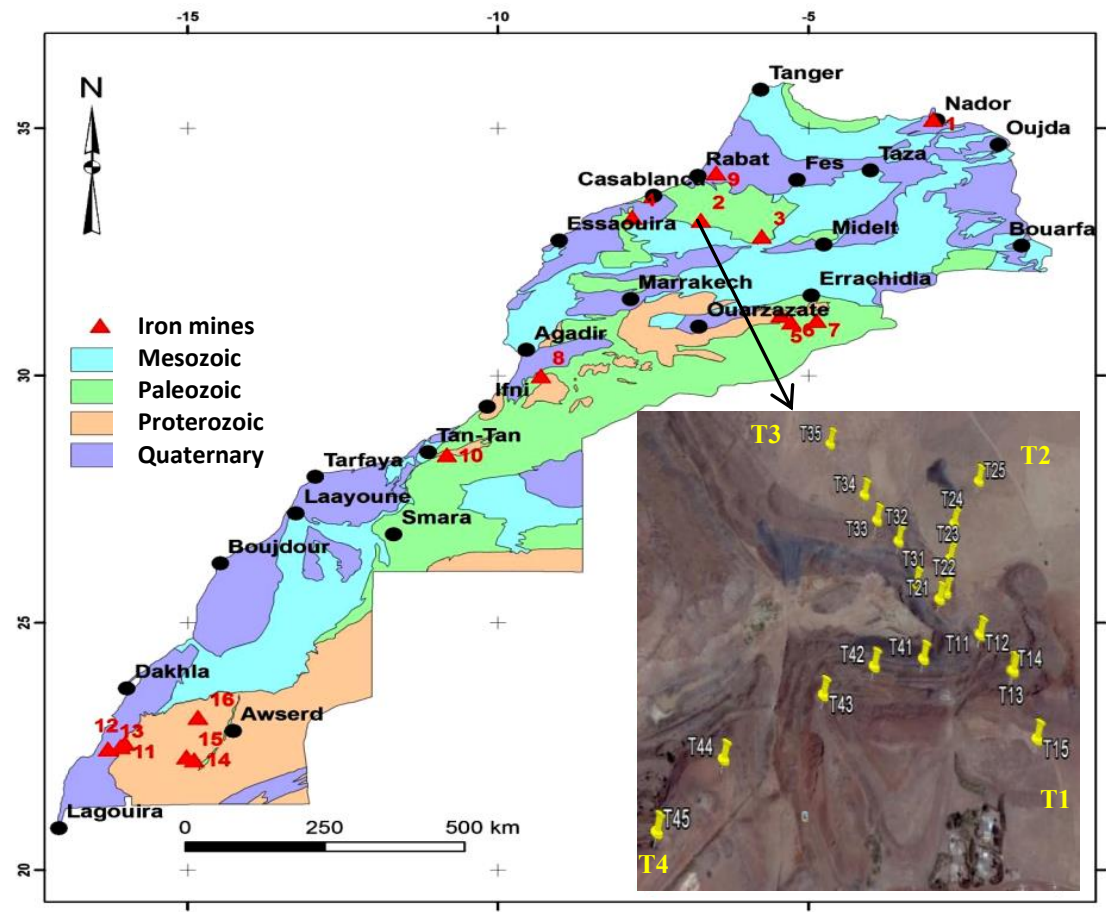

Fig. 1. The sampling map in the abandoned Ait Ammar iron mine site (Number 2).

Metal bioavailable fraction evaluated using the $0.01 \mathrm{M} \mathrm{CaCl}_{2}$ extraction procedure (Houba et al., 1990; NEN, 5704 1996) and metal concentrations were measured by ICP-AES (NCSTR, Rabat, Morocco).

Soil $\mathrm{pH}$ was measured in a soil-water suspension (1:5, w/v extraction ratio) according to the method described in FAOUN (1970). Total organic carbon (TOC) was determined by oxidation with potassium dichromate and titration with ferrous sulphate reagent (Walkley, Black, 1934).

\section{Assessment of soil contamination}

Calculating the degree of contamination by a specified heavy metal obliges that the contaminant metal concentration be compared with a reference material (geochemical background). Such reference material should be an uncontaminated substance that is comparable with the studied samples, as reported with Maanan et al. (2014). The concentration in each point sample was used to calculate the indexes and not the mean levels of transects or rounds.

\section{Enrichment factor}

Enrichment factors (EF) were evaluated to verify heavy metals in soil originate from geogenic or anthropogenic origins. It is frequently supposed that the contents of elements in a natural medium can be justified specially by crust or geogenic origin (Jiang et al., 2013; Li et al., 2015). In this paper, the EF was determined for metals (M) by utilizing the formula:

$$
E F=\frac{\left(\frac{M}{F e}\right) \text { sample }}{\left(\frac{M}{F e}\right) \text { reference }}
$$


where $\mathrm{M}$ is the metal in consideration and Fe is a reference metal. To develop the sensitivity of the EF to the iron mine influence, the soil at a reference site was utilized as a reference. According to Zhang and Liu (2000), EF values between 0.05 and 1.5 reveal that the metal is exclusively from crustal origins or natural developments; however, EF values higher than 1.5 imply that the origins are more probable to be anthropogenic. EF can also help in revealing the contamination degree.

\section{Potential contamination index}

The potential contamination index (Cp) can be evaluated by the equation (Dauvalter, Rognerud, 2001; Maanan et al., 2014).

$$
C p=\frac{M \text { sample } \max }{M \text { reference }}
$$

where $\mathrm{M}$ sample max is the maximum concentration of an element in soil, and $\mathrm{M}$ reference is the value of the same element in a reference soil. Cp values were explained as proposed by Dauvalter and Rognerud (2001), where Cp $\leq 1$ indicates low pollution; $1<\mathrm{Cp} \leq 3$ is moderate pollution; and $\mathrm{Cp}>3$ is severe or very severe pollution.

\section{Contaminant factor and contamination degree}

Contaminant factor (Cf) is the quotient attained by division of the concentration of each metal in the soil by the reference value (Håkanson, 1980; Maanan et al., 2014).

$$
C f=\frac{M \text { sample }}{M \text { reference }}
$$

To simplify contamination control, Håkanson (1980) suggested a method utilizing a diagnostic tool named the contamination degree (Cd). Cd was calculated as the sum of the Cf for each sample:

$$
C d=\sum_{i=1}^{i=n} C f
$$

In accordance with Håkanson (1980): $\mathrm{Cf} \leq 1$ designates low pollution; $1<\mathrm{Cf} \leq 3$ is moderate pollution; $3<\mathrm{Cf} \leq 6$ is considerable pollution; and $\mathrm{Cf}>6$ is very high pollution.

\section{Modified degree of contamination}

The modified degree of contamination $(\mathrm{mCd})$ was presented to approximate the complete degree of pollution using the method (Abrahim, Parker, 2008; Maanan et al., 2014):

$$
m C d=\frac{\sum_{i=1}^{i=n} C f}{n}
$$

where $\mathrm{n}$ is the number of examined elements, $\mathrm{i}$ is the ith pollutant and $\mathrm{Cf}$ is the contamination factor.

\section{Geo-accumulation index}

The geo-accumulation index ( $\left.\mathrm{I}_{\text {geo }}\right)$ was utilized to evaluate the degree of element pollution in soils by balancing the present with original concentrations; however it is hard to find original soils. The $\mathrm{I}_{\text {geo }}$ values of soils in research site were evaluated with the following equation:

$$
I_{g e o}=\log _{2}\left(C_{i} /\left(1.5 B_{i}\right)\right)
$$

where $\mathrm{C}_{\mathrm{i}}$ is the current elements concentration in soil samples and $\mathrm{B}_{\mathrm{i}}$ is the geochemical reference value as defined by Taylor and McLennan (1995). The modified coefficient, constant 1.5, was utilized to characterize the effect of accumulation and geological characteristics and determine the consequence of human activities. $\mathrm{I}_{\text {geo }}$ can be separated into seven classes (Muller, 1969). 


\section{Pollution evaluation of heavy metals}

Pollution indexes (PI) of heavy metals in soils were determined utilizing soil environment quality standards of Canadian soil quality guidelines for the protection of environmental and human health. The equation for determining PI is:

$$
P I=\frac{C i}{S i}
$$

where $C_{i}$ is the actual concentration of element $i$ in soils $\left(\mathrm{mg} \mathrm{kg}^{-1}\right), \mathrm{S}_{\mathrm{i}}$ is the soil quality standard or reference value of element i $\left(\mathrm{mg} \mathrm{kg}^{-1}\right)$. Classifying of heavy metals PIs can be done on four groups (Wu et al., 2014). Furthermore, to present an evaluation of the general contamination class for a sample, the integrated pollution load index (PLI) and/ or the Nemerow integrated pollution index (NIPI) (Nemerow, 1985) can be exercised (Tomlinson et al., 1980; Lu et al., 2014). The NIPI and PLI can be determined utilizing $\left[0.5 \times\left(\mathrm{I}_{\mathrm{Avg}}{ }^{2}+\mathrm{I}_{\mathrm{Max}}{ }^{2}\right)\right]^{1 / 2}$ and $\left(\mathrm{PI}_{1} \times \mathrm{PI}_{2} \times \mathrm{PI}_{3} \times \ldots \times \mathrm{PI}_{\mathrm{n}}\right)^{1 / \mathrm{n}}$, respectively, where $\mathrm{I}_{\text {Avg }}$ is the average value of all contamination indexes of the elements studied, $\mathrm{I}_{\mathrm{Max}}$ is the highest value, $\mathrm{n}$ is the number of elements.

In accordance with Zhang et al. (2011), the PLI is separated in seven classes from none to high contamination to designate the contamination degree. Nevertheless, the grouping of NIPI can be categorized in five classes as reported by Cheng et al. (2014).

\section{Assessment of potential ecological risk}

The index was suggested by Håkanson $(1980,1988)$ and Maanan et al. (2014) to evaluate the heavy metal pollutants. The central function of this index is to designate the pollutant agents and where pollution investigations should be ordered. The index $\mathrm{R}_{\mathrm{I}}$ was presented to evaluate the level of heavy metal contamination in soil, in accordance with the toxicity of heavy metals:

$$
\begin{aligned}
& R_{I}=\sum E_{f}^{i} \\
& E_{f}^{i}=T_{r} x C_{f}
\end{aligned}
$$

where $\mathrm{R}_{\mathrm{I}}$ is determined as the summation of all risk factors for metals in soil, $\mathrm{E}_{\mathrm{f}}^{\mathrm{i}}$ is the individual potential ecological risk factor, $\mathrm{C}_{\mathrm{f}}$ is the contamination factor, and $\mathrm{T}_{\mathrm{r}}^{\mathrm{i}}$ is the toxic response factor, characterizing the potential of metal pollution by representing the toxicity of metals. In accordance with the normalized toxic response factor suggested by Håkanson (1980), $\mathrm{Zn}, \mathrm{Pb}, \mathrm{Cr}, \mathrm{Cd}$ and $\mathrm{Cu}$ have toxic response factors of 1, 5, 2, 30 and 5, respectively. The jargon utilized to define the risk factors $\mathrm{E}_{\mathrm{f}}^{\mathrm{i}}$ and $\mathrm{R}_{\mathrm{I}}$ was proposed by Håkanson (1980).

\section{Statistical analysis}

Multivariate statistical analysis such as non-metric multidimensional scaling analysis (MDS) was used to compare the heavy metal concentrations between sampling sites. MDS was performed in PRIMER 5 (Primer-Eltd, UK). The similarity matrix was found with normalized Euclidean distance similarity of the metal concentration values converted as $\log (\mathrm{x}+1)$. Principal component analysis (PCA) and correlation analysis were used to check for significant relationships between different heavy metals in soil samples and determine the sources of metals pollution for this research, and it is performed using Statistical Package for the Social Science software (SPSS statistics 17.0, USA). The various statistical methods were performed with a $95 \%$ confidence interval (significance $\mathrm{p}<0.05$ ). In the PCA, varimax was used as the rotation method in the analysis following standardization of the data.

\section{Results and discussion}

\section{Soil quality}

Spatial distribution of metals and phosphorus in the surface soil

Table 1 presents the total contents of metals and phosphorus in the topsoil of the research site. Generally the order of element contents in the contaminated soil was $\mathrm{Fe}>\mathrm{P}>>\mathrm{Cr}>$ 
Table 1. Total metals concentrations in the soils of Ait Ammar mining site ( $\left.\mathrm{mg} \mathrm{kg}^{-1}\right)$. T: Transect; R: Round; REF: Reference.

\begin{tabular}{|l|c|c|c|c|c|c|c|}
\hline & Cd & Cr & Cu & Zn & Pb & Fe & P \\
\hline T. 1 & $1.04 \pm 0.36$ & $128.43 \pm 51.47$ & $36.37 \pm 13.30$ & $95.07 \pm 31.39$ & $10.78 \pm 9.85$ & $247684.00 \pm 122152.62$ & $4392.00 \pm 2306.93$ \\
\hline T. 2 & $1.20 \pm 0.41$ & $101.97 \pm 29.75$ & $26.84 \pm 7.23$ & $69.03 \pm 29.93$ & $11.66 \pm 9.91$ & $131718.00 \pm 82478.68$ & $1670.00 \pm 1228.25$ \\
\hline T. 3 & $1.46 \pm 0.92$ & $132.96 \pm 35.89$ & $28.65 \pm 12.13$ & $78.40 \pm 57.82$ & $3.53 \pm 5.11$ & $155662.00 \pm 148759.25$ & $2718.00 \pm 3022.04$ \\
\hline T. 4 & $4.80 \pm 7.80$ & $174.98 \pm 20.65$ & $47.94 \pm 30.28$ & $120.58 \pm 14.71$ & $10.55 \pm 13.12$ & $319502.00 \pm 25391.11$ & $5398.00 \pm 2279.20$ \\
\hline R. 1 & $1.47 \pm 0.96$ & $130.39 \pm 18.19$ & $44.90 \pm 13.24$ & $104.25 \pm 34.01$ & $7.24 \pm 6.42$ & $278557.50 \pm 69085.20$ & $5372.50 \pm 2428.35$ \\
\hline R. 2 & $1.35 \pm 0.40$ & $154.84 \pm 43.46$ & $38.09 \pm 13.12$ & $126.37 \pm 36.85$ & $20.44 \pm 12.76$ & $317665.00 \pm 93544.32$ & $6062.50 \pm 2535.82$ \\
\hline R. 3 & $0.93 \pm 0.47$ & $169.37 \pm 44.63$ & $48.98 \pm 30.09$ & $91.83 \pm 37.15$ & $9.51 \pm 10.41$ & $222835.00 \pm 107807.24$ & $3305.00 \pm 1873.56$ \\
\hline R. 4 & $0.94 \pm 0.29$ & $91.80 \pm 36.96$ & $18.55 \pm 3.16$ & $58.62 \pm 38.89$ & $4.14 \pm 4.82$ & $139042.50 \pm 130180.38$ & $1702.50 \pm 1383.17$ \\
\hline R. 5 & $5.93 \pm 8.35$ & $126.51 \pm 29.49$ & $24.23 \pm 2.98$ & $72.78 \pm 22.41$ & $4.33 \pm 5.44$ & $110107.50 \pm 100866.83$ & $1280.00 \pm 935.33$ \\
\hline REF & 5.14 & 166.02 & 44.76 & 155.38 & 0.92 & 59780.00 & 11020.00 \\
\hline
\end{tabular}

$\mathrm{Zn}>\mathrm{Cu}>\mathrm{Pb}>\mathrm{Cd}$. Fe exhibits the highest content in the topsoil, while mean contents were about $213641.50 \mathrm{mg} \mathrm{kg}^{-1}$ for $\mathrm{Fe}$, and below $2.12 \mathrm{mg} \mathrm{kg}^{-1}$ for $\mathrm{Cd}$. The maximum values of average concentrations for heavy metals in Ait Ammar soils were distributed in T. 1 (Cr), T. 3 $(\mathrm{Zn})$, T. $4(\mathrm{Cd}, \mathrm{Cu}, \mathrm{Pb})$ for transects and for rounds were R. $2(\mathrm{~Pb})$, R. $3(\mathrm{Cr}, \mathrm{Cu})$, R. $4(\mathrm{Zn})$ and R. $5(\mathrm{Cd})$.

Remarkably, the metal concentrations in the reference soil did not reveal regularly lesser values than the soils from the mining area: for $\mathrm{Cd}$ and $\mathrm{Cu}$ the contents were near the mean of the mining area, for $\mathrm{Zn}$ and specifically for $\mathrm{Cr}$ the assessed contents were upper than those noted for all transects and only for $\mathrm{Pb}$, the determined values were lesser than the mean. Moreover, excluding $\mathrm{Cr}$ and $\mathrm{Fe}$, all metals were under the ranges reported by other authors (Boularbah et al., 2006; Iavazzo et al., 2012) in diverse Moroccan abandoned mines.

MDS analyses indicating that samples from mine area are clearly separated (Fig. 2). The plot of the MDS analysis of the metal concentrations does not reveal a clear relation between the soil samples (Fig. 2a, b) and the spatial distribution metals and phosphorus could be determined. This can be related to natural developments of soil and system recovery in the mining activities interrupted 51 years ago (Nouri et al., 2013). In this analysis, the stress level applied to this study evaluated by MDS is 0.08 (Fig. 2), indicating that the two-dimensional representation is valid.
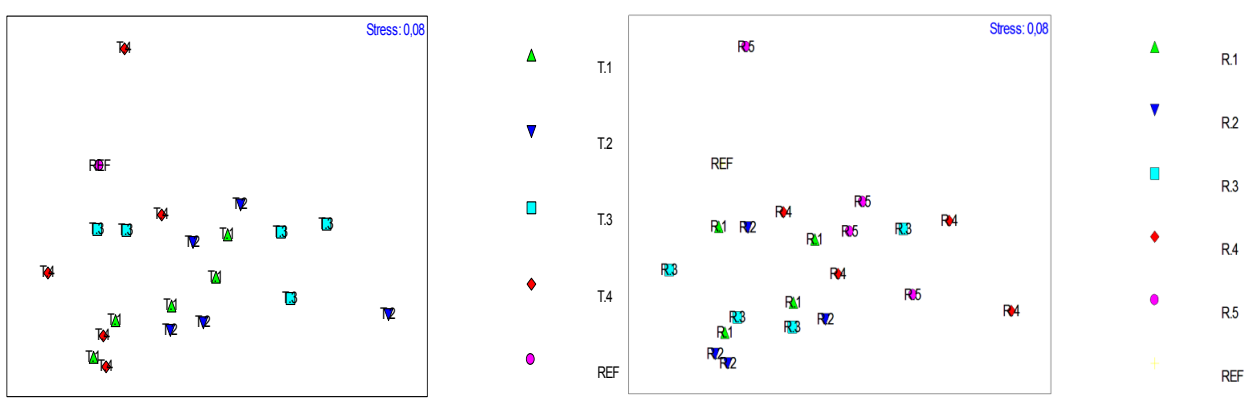

Fig. 2. Non-metric multidimensional scaling analysis of metal concentrations in in the soils of Ait Ammar mining area; Analysis made: (a) by round (R), (b) by transect $(\mathrm{T})$. 
The chemical results of reference soils exploited over soils in unpolluted site are also exposed in Table 1 and were utilized to assess the potential enrichment of soils from Ait Ammar mine with provoked metals (Khan et al., 2008; Luo et al., 2012a). The soil contamination indices for the metals were respected and evaluated.

\section{Bio-availability of phosphorus and metal elements in the topsoil}

Due to the interactions of heavy metals with soil constituents, many soil factors can influence metal bio-accessibility (Luo et al., 2012b). Bio-availability was expressed as the element content extracted by $0.01 \mathrm{M} \mathrm{CaCl}_{2}$ (Fig. 3). In this study, the elements ( $\mathrm{Zn}, \mathrm{P}$ and $\mathrm{Cu}$ ) showed higher bio-availability compared to other metals. Generally, the order for mean values of bio-availability of the elements was as follows: $\mathrm{P}>\mathrm{Zn}>\mathrm{Cu}>\mathrm{Cd}>\mathrm{Fe}>\mathrm{Pb}>\mathrm{Cr}$. $\mathrm{Zn}$ is known to be one of the most mobile metals, since it is highly sensitive to abiotic and biotic-induced changes (Reddy, DeLaune, 2004) and dissociates from the binding groups of the organic matter (Van Hullebusch et al., 2005).

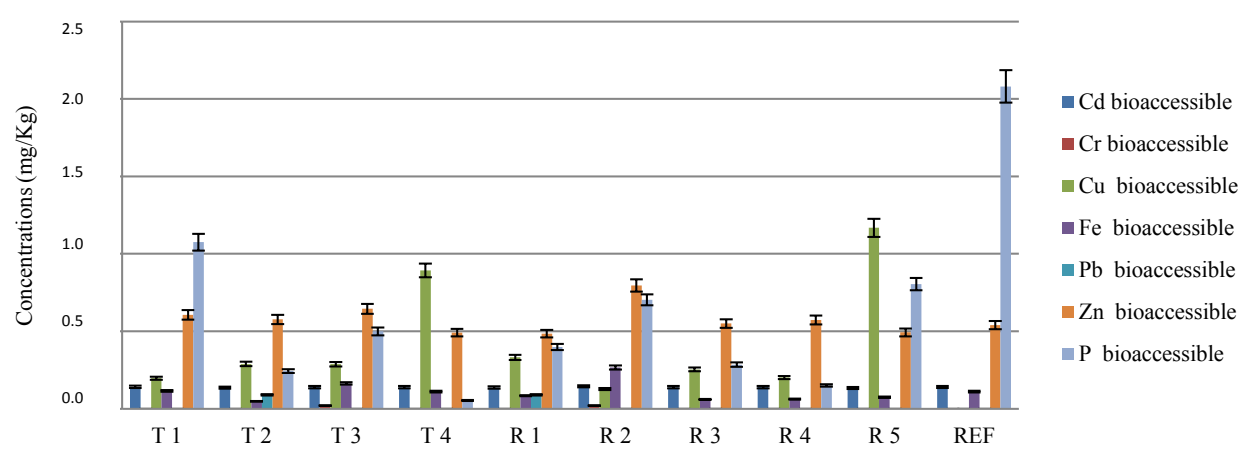

Fig. 3. Extractable metal concentrations in the soils ( $\left.\mathrm{mg} \mathrm{kg}^{-1}\right)$; T: Transect; R: Round; REF: Reference.

The low bio-availability of these elements in the studied area might be due to the stable complexes could be formed with Fe, P (Komárek et al., 2013; Cao et al., 2004; Chen et al., 2006) and were present at high levels in the studied site with high values of chemical variables like $\mathrm{pH}$ and organic matter (Ma et al., 2016).

\section{Influence parameters on metal bio-availability}

The bio-availability of metals in the soils is influenced by $\mathrm{pH}$, organic matter and other variables. The $\mathrm{pH}$ values of mining soil samples are slightly acids to neuters, ranging between 6.4 and 7.1 (Fig. 4). The $\mathrm{pH}$ of soil is very essential for mobility because metal accessibility is low when the $\mathrm{pH}$ is about 6.5 to 7 (Ma et al., 2016). The TOC levels in investigated soil samples range between 0.43 and $1.48 \%$ (Fig. 4). It is reported that contaminated mining soils are described by minimal nutrient content (Freitas et al., 2004). There is no significant spatial 


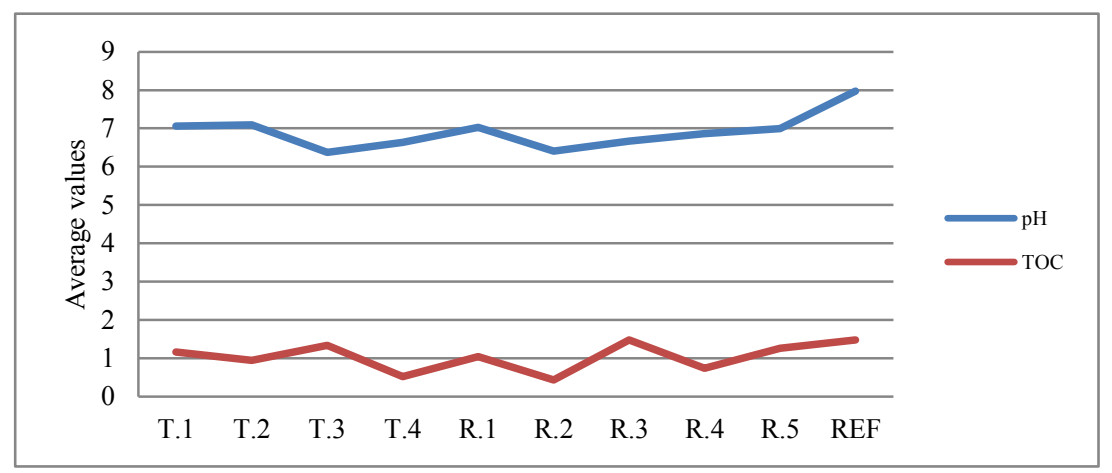

Fig. 4. Mean values of soil pH and total organic carbon (TOC, \%); T: Transect; R: Round; REF: Reference.

variation in the TOC and $\mathrm{pH}$ values. Comparable levels were reported in soils near other abandoned Moroccan mining area (Boularbah et al., 2006; Iavazzo et al., 2012).

In conclusion, the low availability of metal due mainly to the high contents of Fe and $\mathrm{P}$ in the research area first and second to the $\mathrm{pH}$ ranging between 6.4 and 7.1, implying a relative harmless environment. For more physico-chemical parameters, see Nouri et al. (2014).

Determining geochemical relations between metals and phosphorus for soils from Ait Ammar iron mine

To assess the extent of metal pollution in the research site and determine its origins, a factor was analysed utilizing the correlation matrix levels of all the elements in the Ait Ammar soil samples. The correlation matrix utilized in the analysis deliver significant instruments for a comprehending the origin identification and the dynamics of the contaminants.

T a b l e 2. Correlation coefficient for metals and phosphorus of the raw data in mining area soils of Ait Ammar.

\begin{tabular}{|c|c|c|c|c|c|c|c|c|c|c|c|}
\hline & Cd & $\mathrm{Cr}$ & $\mathrm{Cu}$ & Zn & $\mathbf{P b}$ & $\mathrm{Fe}$ & $\mathbf{P}$ & $\mathrm{Cd}^{\mathrm{b}}$ & $\mathrm{Cu}^{\mathrm{b}}$ & $\mathrm{Fe}^{\mathrm{b}}$ & $\mathrm{Zn}^{\mathrm{b}}$ \\
\hline Cd & 1 & 0.164 & -0.145 & 0.070 & -0.180 & 0.160 & -0.017 & -0.011 & $0.988^{\star *}$ & -0.046 & -0.114 \\
\hline $\mathrm{Cr}$ & & 1 & $0.531^{\star}$ & $0.652^{\star *}$ & 0.042 & $0.662^{\star \star}$ & $0.525^{\star}$ & 0.179 & 0.139 & 0.344 & 0.001 \\
\hline $\mathrm{Cu}$ & & & 1 & $0.579^{* *}$ & 0.111 & $0.576^{\star *}$ & $0.611^{\star *}$ & 0.045 & -0.159 & -0.084 & -0.113 \\
\hline $\mathrm{Zn}$ & & & & 1 & 0.265 & $0.889^{\star *}$ & $0.791^{\star *}$ & 0.101 & -0.009 & 0.380 & 0.000 \\
\hline $\mathbf{P b}$ & & & & & 1 & 0.304 & $0.489^{\star}$ & 0.025 & -0.187 & 0.131 & -0.065 \\
\hline $\mathrm{Fe}$ & & & & & & 1 & $0.882^{\star *}$ & 0.211 & 0.085 & 0.237 & -0.023 \\
\hline $\mathbf{P}$ & & & & & & & 1 & 0.122 & -0.089 & 0.254 & -0.113 \\
\hline$C d^{b}$ & & & & & & & & 1 & -0.066 & 0.441 & $0.800^{* *}$ \\
\hline $\mathrm{Cu}^{\mathrm{b}}$ & & & & & & & & & 1 & -0.121 & -0.197 \\
\hline $\mathrm{Fe}^{\mathrm{b}}$ & & & & & & & & & & 1 & $0.536^{*}$ \\
\hline $\mathrm{Zn}^{\mathrm{b}}$ & & & & & & & & & & & 1 \\
\hline
\end{tabular}

Notes: ${ }^{* *}$ - Correlation is significant at the 0.01 level (2-tailed); ${ }^{*}$ Correlation is significant at the 0.05 level (2-tailed);

b- Bioavailable. 
Correlation analysis was employed to investigate the relationships among the metals and phosphorus; the Pearson correlation coefficients between the determined chemical variables are shown in Table 2 . The results reveal that there are numerous significant correlation coefficients and some are very strong. Remarkably, high correlations with a significant level at $\mathrm{p}$ $<0.01$ were obtained between the elemental pairs $\mathrm{Zn}-\mathrm{Cr}(\mathrm{r}=0.652), \mathrm{Fe}-\mathrm{Cr}(\mathrm{r}=0.662)$, Fe-Cu $(\mathrm{r}=0.576), \mathrm{Fe}-\mathrm{Zn}(\mathrm{r}=0.889), \mathrm{P}-\mathrm{Cu}(\mathrm{r}=0.611), \mathrm{P}-\mathrm{Zn}(\mathrm{r}=0.791)$ and $\mathrm{P}-\mathrm{Fe}(\mathrm{r}=0.882)$ revealing a common source for these elements. $\mathrm{Cr}$ is significantly correlated $(\mathrm{p}<0.05)$ with $\mathrm{Cu}(\mathrm{r}$ $=0.531)$ and with $\mathrm{P}(\mathrm{r}=0.525)$ and $\mathrm{Pb}-\mathrm{P}(\mathrm{r}=0.489)$. Finally, $\mathrm{Cd}$ was highly associated with extractable $\mathrm{Cu}(\mathrm{r}=0.988)$ and inversely correlated with $\mathrm{Cu}(\mathrm{r}=-0.145), \mathrm{Pb}(\mathrm{r}=-0.180)$ and $\mathrm{P}$ $(\mathrm{r}=-0.017)$ indicating the different source that delivers the soils with $\mathrm{Cd}$ balanced to $\mathrm{Cu}, \mathrm{Pb}$ and $\mathrm{P}$. Notably, negative correlations between $\mathrm{Cd}$ and $\mathrm{Pb}$ and any other elements $(\mathrm{Cr}, \mathrm{Cu}, \mathrm{Fe}$, $\mathrm{P}$ and $\mathrm{Zn}$ ) are very weak ( $\mathrm{p}>0.05$ ), which implies a different source of $\mathrm{Cd}$ and $\mathrm{Pb}$.

The results of the correlation analysis suggest that metals in soils from Ait Ammar may originate from both natural and anthropogenic sources. To identify the source of elements in soils, a principal component analysis (PCA) was performed, which has been considered to be efficient for the implementation of source identification (Anju, Banerjee, 2012).

The results of PCA for the concentrations in soils from Ait Ammar iron mine are offered in Tables 3 and 4 . Two components with eigenvalues higher than 1.00 were extracted. The PCA method resulted in a reduction of the initial dimension of the dataset to two com-

$\mathrm{T}$ a b l e 3. Total variance explained and rotated component matrix of PCA of elemental concentrations for soils from Ait Ammar mine.

\begin{tabular}{|c|c|c|c|c|c|c|c|c|c|}
\hline \multirow{2}{*}{ Component } & \multicolumn{3}{|c|}{ Initial Eigenvalues } & \multicolumn{3}{|c|}{$\begin{array}{c}\text { Extraction Sums of Squared } \\
\text { Loadings }\end{array}$} & \multicolumn{3}{|c|}{$\begin{array}{c}\text { Rotation Sums of Squared } \\
\text { Loadings }\end{array}$} \\
\hline & Total & $\begin{array}{c}\% \text { of } \\
\text { Variance }\end{array}$ & $\begin{array}{c}\text { Cumulative } \\
\%\end{array}$ & Total & $\begin{array}{c}\% \text { of } \\
\text { Variance }\end{array}$ & $\begin{array}{c}\text { Cumulative } \\
\% \\
\end{array}$ & Total & $\begin{array}{c}\% \text { of } \\
\text { Variance }\end{array}$ & $\begin{array}{c}\text { Cumulative } \\
\%\end{array}$ \\
\hline 1 & 3,821 & 54,591 & 54,591 & 3,821 & 54,591 & 54,591 & 3,779 & 53,989 & 53,989 \\
\hline 2 & 1,262 & 18,027 & 72,618 & 1,262 & 18,027 & 72,618 & 1,304 & 18,629 & 72,618 \\
\hline 3 & 0,911 & 13,015 & 85,632 & & & & & & \\
\hline 4 & 0,405 & 5,786 & 91,418 & & & & & & \\
\hline 5 & 0,378 & 5,394 & 96,812 & & & & & & \\
\hline 6 & 0,160 & 2,291 & 99,104 & & & & & & \\
\hline 7 & 0,063 & 0,896 & 100,000 & & & & & & \\
\hline
\end{tabular}

$\mathrm{T}$ a b l e 4 . The computed weighted values for each metal (significant loading factors are marked in bold).

\begin{tabular}{|l|c|c|}
\hline Component & $\mathbf{1}$ & $\mathbf{2}$ \\
\hline Fe & $\mathbf{0 . 9 5 0}$ & 0.021 \\
\hline $\mathbf{Z n}$ & $\mathbf{0 . 9 1 7}$ & 0.046 \\
\hline $\mathbf{P}$ & $\mathbf{0 . 8 8 6}$ & 0.296 \\
\hline $\mathbf{C r}$ & $\mathbf{0 . 7 8 9}$ & -0.248 \\
\hline $\mathbf{C u}$ & $\mathbf{0 . 7 1 9}$ & 0.153 \\
\hline $\mathbf{C d}$ & 0.154 & $\mathbf{- 0 . 7 8 9}$ \\
\hline Pb & 0.294 & $\mathbf{0 . 7 1 1}$ \\
\hline
\end{tabular}

ponents, explaining $72.618 \%$ of the data variation. Loading plots of the components are exposed in Fig. 5. According to the rotated component matrix, PC1 and PC2 accounted for 53.99 and $18.63 \%$ of the total variance respectively. Metals $\mathrm{Cr}, \mathrm{Cu}, \mathrm{Zn}$ and $\mathrm{Fe}$ were discovered to be strongly associated with $\mathrm{P}$ in the first component (PC1) (Table 4), which mostly originated from natural sources, because $\mathrm{Fe}$ is mainly derived from lithogenic sources (Pejman et al., 2015) 
and their mean concentrations were comparable to the corresponding reference levels, as reported by Zhang et al. (2014). PC2 includes $\mathrm{Cd}$ and $\mathrm{Pb}$ with opposite loadings, which can be identified as a tracer of anthropogenic pollution sources for $\mathrm{Cd}$ and $\mathrm{Pb}$. It is documented that the essential origins of $\mathrm{Cd}$ and $\mathrm{Pb}$ were anthropogenic counting industrial and mining activities (Wang et al., 2015; Zhou et al., 2015; Wen et al., 2015), which was comparable with our conclusions.

PCA results are consistent with correlations matrices pointing out that most of metal variability in Ait Ammar soils can be explained by entirely natural inputs by parent materials. These results are consistent with those from next sections of contamination indices and ecological risk, which indicate that the topsoil was contaminated by $\mathrm{Cd}$ and $\mathrm{Pb}$, whereas the $\mathrm{Cr}, \mathrm{Cu}, \mathrm{Zn}$, and $\mathrm{P}$ in the topsoil originated from lithogenic sources.

Correlation matrix and PCA were utilized in this analysis to comprehend the major differences between the metals and phosphorus. A significant positive correlation is detected between $\mathrm{Cu}, \mathrm{Cr}, \mathrm{Zn}, \mathrm{Fe}$ and $\mathrm{P}$, signifying that these metals are originated from comparable origins. PCA classifies two key classes of similarities: one contained an anthropogenic origins and another a natural source.

\section{Indices of soil contamination}

\section{Enrichment factor of heavy metals and phosphorus}

To assess the degree of anthropogenic influence, the enrichment factor indices of metals and phosphorus in soils have been calculated. The enrichment factor values were listed in Table 5. The average EF values were in the following order: $\mathrm{Pb}(6.22)>>\mathrm{Cr}(0.44)>\mathrm{Cu}$ $(0.38)>\mathrm{Zn}(0.24)>\mathrm{Cd}(0.17)>\mathrm{P}(0.09)$. In general, EF values of $0.05-1.5$ can be considered to be in the range of natural variability, whereas EF values greater than 1.5 suggest that the sources are more likely to have a partially anthropogenic origin (Zhang, Liu, 2000). These results further demonstrate that the topsoil was contaminated by $\mathrm{Pb}$, whereas the $\mathrm{Cr}$, $\mathrm{Cu}, \mathrm{Zn}, \mathrm{Cd}$, and $\mathrm{P}$ in the topsoil originated from lithogenic sources.

The results showed that the average $\mathrm{EF}$ values of $\mathrm{Cd}, \mathrm{Cr}, \mathrm{Cu}, \mathrm{Zn}, \mathrm{Pb}$ and $\mathrm{P}$ were 0.17 , $0.44,0.38,0.24,6.22$ and 0.09 , respectively. The mean $\mathrm{EF}$ values of $\mathrm{Cd}, \mathrm{Cr}, \mathrm{Cu}, \mathrm{Zn}$ and $\mathrm{P}$ were $<2$, suggesting relatively minimal enrichment. However, the mean $\mathrm{EF}$ values of $\mathrm{Pb}$ were higher than 1.5, implying anthropogenic impact to the metal levels in iron mining 


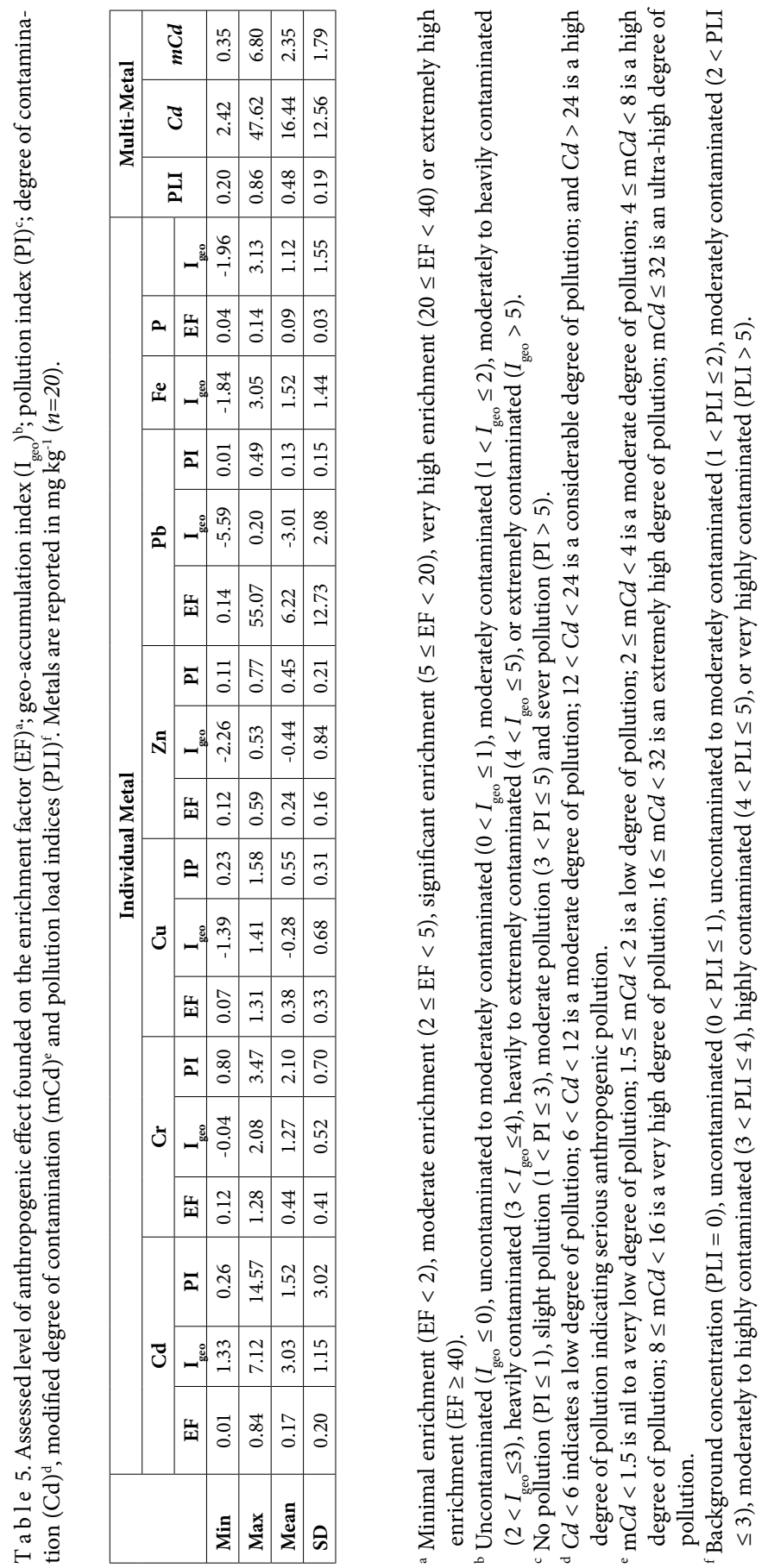


soils (Zhang, Liu, 2000). Table 6 shows the percentage of class distribution of pollution assessment for heavy metals in soils with enrichment factor. It can be seen from the table that the EF values of all heavy metals and phosphorus in soils were lower than 2 , showing deficiency or minimal pollution. Forty per cent of the EF values for $\mathrm{Pb}$ surpassing 2 , including $5 \%$ of samples showing extreme enrichment and other 5\% samples implying very high enrichment, revealed that $\mathrm{Pb}$ in Ait Ammar iron mine soils corresponded to relatively serious contamination.

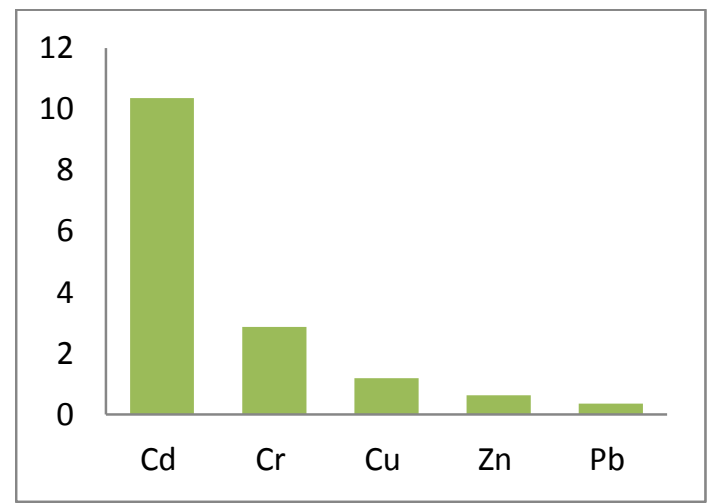

Fig. 6. Nemerow integrated pollution index of heavy metals for the Ait Ammar soil samples.

\section{Pollution indexes of heavy metals}

The pollution index can be used to provide a relative ranking of contamination levels. As shown in Table 5, the PI values of $\mathrm{Pb}, \mathrm{Cu}$ and $\mathrm{Zn}$ are almost below 1 . Chromium is the only metal with almost all the collected samples showing pollution indexes above 1 with maxima of 3.47. Cadmium for a small number of soils also demonstrates a relative enrichment with respect to the maximum background value. Interestingly, the enrichment of soil samples with $\mathrm{Cd}$ is severely higher in T.4.5 sample. The maximum values of pollution index for $\mathrm{Cd}$ are14.57, indicating anthropogenic origin for this metal in T.4.5.

In addition, the degree of contamination of soils is low $(1<\mathrm{PI} \leq 3)$ for all elements, and the proportion of samples, which have moderate $(3<\mathrm{PI} \leq 5)$ and high $(\mathrm{PI}>5)$ contamination, is $15 \%$ for $\mathrm{Cr}$ and $5 \%$ for $\mathrm{Cd}$, respectively (Table 6). These results indicate that iron mine soils of Ait Ammar are contaminated by $\mathrm{Cd}, \mathrm{Cr}, \mathrm{Cu}, \mathrm{Pb}$, and $\mathrm{Zn}$, but contamination is minimal for the last three metals and moderate for the two first. Furthermore, assessed to the Canadian soil quality guidelines (CCME, 1999), only $\mathrm{Cd}, \mathrm{Cu}, \mathrm{Zn}$ and $\mathrm{Pb}$ mean concentrations are lower than the recommended values of 22, 91, 360 and $600 \mathrm{mg} / \mathrm{kg}$ respectively whereas $\mathrm{Cr}$ for all transects and rounds exceeds the limit of $87 \mathrm{mg} / \mathrm{kg}$.

Furthermore, to give a comprehensive situation of soil metals, the integrated pollution load index (PLI) for each sample was considered. The results showed that the PLI values of heavy metals in iron mine soils ranged from 0.20 to 0.86 with an average of 0.48 , also indicating no pollution. Especially, the PLI values of elements in all soil samples were below than 1 , showing no to low pollution according to Tomlinson et al. (1980).

In the present study, the Nemerow integrated pollution index (NIPI) of heavy metals in soils was calculated. Fig. 6 shows the NIPI values of soil metals. It can be seen from Fig. 6 that the comprehensive pollution levels varied widely among different samples. The NIPI values in soil ranged from 0.36 to 10.36 . Investigations showed that the soils were slightly polluted with $\mathrm{Cu}$, moderately polluted with $\mathrm{Cr}$ and highly polluted particularly with $\mathrm{Cd}$. 


\section{Pollution assessment of soil metals using geochemical indicators}

Table 5 shows the results of the geo-accumulation index $\left(\mathrm{I}_{\text {geo }}\right)$ values for metals and phosphorus in Ait Ammar mining soils. As shown in Table 5, the $I_{\text {geo }}$ values of Cd vary the most, varying from the moderately contaminated level to the extremely contaminated level. In addition, the $\mathrm{I}_{\text {geo }}$ values of Cr vary from the unpolluted level to moderately contaminated level. However, the average $\mathrm{I}_{\text {geo }}$ values for $\mathrm{Pb}, \mathrm{Zn}$, and $\mathrm{Cu}$ were lower (negative) than other element types.

Table 6 lists the percentages of class distribution for pollution assessment of heavy metals using $\mathrm{I}_{\text {geo }}$. In particular, the $40 \%$ of the $\mathrm{I}_{\text {geo }}$ values of Cd were higher than 3 , suggesting that iron mining soils should be heavily contaminated by Cd (Muller, 1969). The result also can be drawn from Table 6 that the $I_{\text {geo }}$ values for Cd in 5\% samples are extremely contaminated level.

T a b l e 6. Percentage of class distribution of pollution ( $\mathrm{I}_{\text {geo }}, \mathrm{EF}$ and PI).

\begin{tabular}{|c|c|c|c|c|c|c|c|c|}
\hline & & Cd & $\mathrm{Cr}$ & $\mathrm{Cu}$ & $\mathrm{Zn}$ & $\mathbf{P b}$ & $\mathrm{Fe}$ & $\mathbf{P}$ \\
\hline \multirow{7}{*}{$I_{\text {geo }}$} & $\mathrm{I}_{\mathrm{geo}} \leq 0$ & & $5 \%$ & $70 \%$ & $60 \%$ & $95 \%$ & $25 \%$ & $25 \%$ \\
\hline & $0<\mathrm{I}_{\mathrm{geo}} \leq 1$ & & $20 \%$ & $25 \%$ & $40 \%$ & $5 \%$ & $5 \%$ & $10 \%$ \\
\hline & $1<\mathrm{I}_{\mathrm{geo}} \leq 2$ & $15 \%$ & $70 \%$ & $5 \%$ & & & $15 \%$ & $30 \%$ \\
\hline & $2<\mathrm{I}_{\mathrm{geo}} \leq 3$ & $45 \%$ & $5 \%$ & & & & $50 \%$ & $30 \%$ \\
\hline & $3<\mathrm{I}_{\mathrm{geo}} \leq 4$ & $30 \%$ & & & & & $5 \%$ & $5 \%$ \\
\hline & $4<\mathrm{I}_{\mathrm{geo}} \leq 5$ & $5 \%$ & & & & & & \\
\hline & $\mathrm{I}_{\mathrm{geo}}>5$ & $5 \%$ & & & & & & \\
\hline \multirow{5}{*}{ EF } & $\mathrm{EF}<2$ & $100 \%$ & $100 \%$ & $100 \%$ & $100 \%$ & $60 \%$ & & $100 \%$ \\
\hline & $2 \leq \mathrm{EF}<5$ & & & & & $15 \%$ & & \\
\hline & $5 \leq \mathrm{EF}<20$ & & & & & $15 \%$ & & \\
\hline & $20 \leq \mathrm{EF}<40$ & & & & & $5 \%$ & & \\
\hline & $\mathrm{EF} \geq 40$ & & & & & $5 \%$ & & \\
\hline \multirow{4}{*}{ PI } & $\mathrm{PI} \leq 1$ & $75 \%$ & $5 \%$ & $95 \%$ & $100 \%$ & $100 \%$ & & \\
\hline & $1<\mathrm{PI} \leq 3$ & $20 \%$ & $80 \%$ & $5 \%$ & & & & \\
\hline & $3<\mathrm{PI} \leq 5$ & & $15 \%$ & & & & & \\
\hline & $\mathrm{PI}>5$ & $5 \%$ & & & & & & \\
\hline
\end{tabular}

The $\mathrm{I}_{\text {geo }}$ values of Fe and P vary the most, ranging from the uncontaminated level to the heavily contaminated level. In particular, the $70 \%$ and $65 \%$ percentile $\mathrm{I}_{\text {geo }}$ values of $\mathrm{Fe}$ and $\mathrm{P}$ were higher than 1, respectively, suggesting that iron mining soils should be moderately contaminated by Fe and P. It is well known that different land use patterns, intensity of human activities, pollution history, and distance to emission sources may affect soil pollution to various degrees (Lee et al., 2006).

In summary, this study reveals that the surface soils in the iron mine area have been heavily contaminated with $\mathrm{Cd}$, moderately contaminated with $\mathrm{Cr}$, Fe and $\mathrm{P}$ and unpolluted with $\mathrm{Pb}, \mathrm{Cu}$ and $\mathrm{Zn}$, according to $\mathrm{I}_{\text {geo }}$ values. The average $\mathrm{I}_{\text {geo }}$ value indicated that the pollution degree of seven elements decreased in following sequence: $\mathrm{Cd}>\mathrm{Fe}>\mathrm{Cr}>\mathrm{P}>\mathrm{Cu}>\mathrm{Zn}>\mathrm{Pb}$. 


\section{Potential contamination index}

The Cp for seven investigated elements for Ait Ammar site is presented in Fig. 7. They demonstrate that $\mathrm{Zn}$ and $\mathrm{P}$ are at low contamination, $\mathrm{Cr}$ and $\mathrm{Cu}$ are at moderate contamination and $\mathrm{Pb}$, $\mathrm{Cd}$ and $\mathrm{Fe}$ are at severe or very severe contamination levels. The highest value assigned for $\mathrm{Pb}$. $\mathrm{Pb}, \mathrm{Cd}$ and $\mathrm{Fe}$ metals at the sampling area revealed the highest degree of contamination impact focused on the Cp of the soil of Ait Ammar iron mine.

Contaminant factor and contamination degree

In the current analysis, the Cd was described as the summation of all Cf for iron mine. These values are presented in Tables 7 and 5. The degree of contamination varied from 2.42 to 47.62 with a mean of 16.44 , which approves that some mine soils have a great degree of pollution.

\section{Modified degree of contamination}

In the Ait Ammar iron mine, the revised Håkanson formula was utilized to determine the $\mathrm{mCd}$ for all the studied elements $(\mathrm{Cd}, \mathrm{Cr}, \mathrm{Cu}, \mathrm{Zn}, \mathrm{Pb}, \mathrm{Fe}$ and $\mathrm{P})$. The results are shown in Table 5 . The values vary from 0.35 to 6.80 with an average 2.35 , representing that the investigate site presents a moderate degree of pollution, with anthropogenic contamination.

\section{Potential ecological risk}

The Håkanson index delivers a measurable approach of precisely separating the level of possible hazards. Nevertheless, one disadvantage of this method is that it contains a great degree of subjectivity and ignores the weighting function or united antagonism of numerous metals. In general, the potential ecological risk index and solo metal pollution index produced diverse calculation results (Maanan et al., 2014).

The potential ecological risk factors $\mathrm{E}_{\mathrm{i}}^{\mathrm{f}}$ for each metal and the $\mathrm{R}_{\mathrm{I}}$ for all five heavy metals combined of the research area were summarized in Table 8 . The results show that the single heavy metal pollution index underlines the risk that $\mathrm{Pb}$ and $\mathrm{Cd}$ cause to the human and the environment. For other elements $(\mathrm{Cr}, \mathrm{Cu}$ and $\mathrm{Zn})$, the $\mathrm{E}_{\mathrm{i}}^{\mathrm{f}}$ indices were generally low. The $\mathrm{E}_{\mathrm{i}}^{\mathrm{f}}$ 
T a b l e 8. Heavy metal potential ecological risk indices of Ait Ammar mine.

\begin{tabular}{|c|c|c|c|c|c|c|}
\hline \multicolumn{6}{|c|}{ Individual metal } & \multirow{3}{*}{ Multi-metal $\mathrm{R}_{\mathrm{I}}^{\mathrm{b}}$} \\
\hline & \multicolumn{5}{|c|}{$\mathbf{E}_{\mathrm{i}}^{\mathrm{fa}}$} & \\
\hline & Cd & $\mathrm{Cr}$ & $\mathrm{Cu}$ & $\mathrm{Zn}$ & $\mathbf{P b}$ & \\
\hline Min & 2.16 & 0.61 & 1.60 & 0.14 & 3.39 & 11.68 \\
\hline $\operatorname{Max}$ & 119.15 & 2.68 & 11.13 & 0.99 & 188.48 & 995.68 \\
\hline Mean & 12.41 & 1.62 & 3.90 & 0.58 & 49.78 & 273.20 \\
\hline SD & 24.72 & 0.54 & 2.21 & 0.27 & 56.93 & 370.69 \\
\hline
\end{tabular}

${ }^{a} \mathrm{E}_{\mathrm{i}}^{\mathrm{f}}<40$ indicates a low potential ecological risk; $40<\mathrm{E}_{\mathrm{i}}^{\mathrm{f}}<80$ is a moderate ecological risk; $80<\mathrm{E}_{\mathrm{i}}^{\mathrm{f}}<160$ is a considerable ecological risk; $160<\mathrm{E}_{\mathrm{i}}^{\mathrm{f}}<320$ is a high ecological risk and $\mathrm{E}_{\mathrm{i}}^{\mathrm{f}}>320$ is a very high ecological risk.

${ }^{\mathrm{b}} \mathrm{R}_{\mathrm{I}}<95$ indicates a low potential ecological risk; $95<\mathrm{R}_{\mathrm{I}}<190$ is a moderate ecological risk; $190<\mathrm{R}_{\mathrm{I}}<380$ is a considerable ecological risk and $\mathrm{R}_{\mathrm{I}}>380$ is a very high ecological risk.

indices for individual metals showed that the gravity of contamination of the five heavy metals diminutions in this order: $\mathrm{Pb}>\mathrm{Cd}>\mathrm{Cu}>\mathrm{Cr}>\mathrm{Zn}$. Based on the $\mathrm{R}_{\mathrm{r}}$, the minimum, mean, and maximum potential ecological risk grades are low, considerable, and very high, respectively, which can be essentially qualified to the fact that the study site is a considerable ecological risk.

\section{Conclusion}

Different useful tools, methods and indices were employed to evaluate soil pollution and ecological risk index in Ait Ammar abandoned iron mine, Morocco. In this study, we investigated the concentrations of phosphorus and metals, including $\mathrm{Cd}, \mathrm{Cr}, \mathrm{Cu}, \mathrm{Pb}$ and $\mathrm{Zn}$ and $\mathrm{Fe}$ in iron mine soils. The results of the correlation matrix and PCA indicated that $\mathrm{Fe}, \mathrm{Cu}, \mathrm{Zn}$, $\mathrm{Cr}$ and $\mathrm{P}$ mainly originated from comparable sources and $\mathrm{Cd}$ and $\mathrm{Pb}$ is mostly derived from anthropogenic sources. According to the results of potential ecological risk index $\left(\mathrm{R}_{\mathrm{I}}\right)$, pollution index (PI), geo-accumulation index $\left(\mathrm{I}_{\mathrm{geo}}\right)$, enrichment factor, potential contamination index, contaminant factor and degree of contamination $(\mathrm{Cd})$, based on the averages, considerable pollution of metals in soils of study area was observed. For individual metal, only $\mathrm{Pb}$ had high ecological risk for some site samples, without neglect the Cd impact.

The increasing of metal concentrations above the threshold is bound to have harmful effects on human. Therefore, it is necessary to design an environmental strategy not only to manage but also monitor the same with priority.

\section{Acknowledgements}

The authors gratefully acknowledge the financial support provided by the North Atlantic Treaty Organization (NATO), under the Program Science for Peace (Ref. SfP.983311).

\section{References}

Abrahim, G.M.S. \& Parker R.J. (2008). Assessment of heavy metal enrichment factors and the degree of contamination in marine sediments from Tamaki Estuary Auckland, New Zealand. Environ. Monit. Assess., 136, 227-238. DOI: $10.1007 / \mathrm{s} 10661-007-9678-2$. 
Anju, M. \& Banerjee D.K. (2012). Multivariate statistical analysis of heavy metals in soils of a Pb-Zn mining area, India. Environ. Monit. Assess., 184, 4191-4206. DOI: 10.1007/s10661-011-2255-8.

Boularbah, A., Schwartz, C., Bitton, G. \& Morel J.L. (2006). Heavy metal contamination from mining sites in South Morocco: 1. Use of a biotest to assess metal toxicity of tailings and soils metal accumulation and toxicity in plants. Chemosphere, 63, 802-810. DOI: 10.1016/j.chemosphere.2005.07.079.

Cao, R.X., Ma, L.Q., Chen, M., Singh, S.P. \& Harris W.G. (2003). Phosphate-induced metal immobilization in a contaminated site. Environ. Pollut., 122, 19-28. DOI: 10.1016/S0269-7491(02)00283-X.

CCME (Canadian Council of Ministers of the Environment), 1999 and updates. Canadian Environmental Quality Guidelines. Canadian Council of Ministers of the Environment, Winnipeg. Published 1999, updated through 2014. Available online at http://ceqg-rcqe.ccme.ca/

Chen, S.B., Zhua, Y.G. \& Ma Y.B. (2006). The effect of grain size of rock phosphate amendment on metal immobilization in contaminated soils. J. Hazard. Mater., 134, 74-79. DOI: 10.1016/j.jhazmat.2005.10.027.

Cheng, H.X., Li, M., Zhao, C.D., Li, K., Peng, M., Qin, A.H. \& Cheng X.M. (2014). Overview of trace metals in the urban soil of 31 metropolises in China. Journal of Geochemical Exploration, 139, 31-52. DOI: 10.1016/j. gexplo.2013.08.012.

Dauvalter, V. \& Rognerud S. (2001). Heavy metal pollution in sediments of the Pasvik River drainage. Chemosphere, 42, 9-18. DOI: 10.1016/S0045-6535(00)00094-1.

Fairbrother, A., Wenstel, R., Sappington, K. \& Wood W. (2007). Framework for metals risk assessment. Ecotoxicol. Environ. Saf., 68, 145-227. DOI: 10.1016/j.ecoenv.2007.03.015.

FAOUN, (Food and Agriculture Organization of the United Nations) (1970). Physical and chemical methods of soil and water analysis. FAO Soils Bulletin, 10, 1-275.

Freitas, H., Prasad, M.N.V. \& Pratas J. (2004). Plant community tolerant to trace elements growing on the degraded soils of São Domingos mine in the south east of Portugal: environmental implications. Environ Int., 30, 65-72. DOI: $10.1016 /$ S0160-4120(03)00149-1.

Håkanson, L. (1980). Ecological risk index for aquatic pollution control: a sediment logical approach. Water Research, 14, 975-1001. DOI: 10.1016/0043-1354(80)90143-8.

Håkanson, L. (1988). Metal monitoring in coastal environments. In U. Seeliger, L.D. Lacerda \& S.R. Patchineelam (Eds.), Metals in coastal environments of Latin America (pp. 240-257). Berlin: Springer-Verlag.

Homa, J., Niklinska, M. \& Plytycz B. (2003). Effect of heavy metals on coelomocytes of the earthworm Allolobophora chlorotica. Pedobiologia, 47, 640-645. DOI: 10.1078/0031-4056-00239.

Houba, V.J.G, Novozamsky, I., Lexmond, T.M. \& Van Der Lee J.J. (1990). Applicability of $0.01 \mathrm{M} \mathrm{CaCl} 2$ as a single extraction solution for the assessment of the nutrient status of soils and other diagnostic purposes. Commun. Soil Sci. Plant Anal., 21, 2281-2290. DOI: 10.1080/00103629009368380.

Iavazzo, P., Ducci, D., Adamo, P., Trifuoggi, M., Migliozzi, A. \& Boni M. (2012). Impact of past mining activity on the quality of water and soil in the high Moulouya Valley (Morocco). Water Air Soil Pollut., 223, 573-589. DOI: 10.1007/s11270-011-0883-9.

Jiang, J.B., Wang, J., Liu, S.Q., Lin, C.Y., He, M.C. \& Liu X.T. (2013). Background, baseline, normalization, and contamination of heavy metals in the Liao River Watershed sediments of China. Journal of Asian Earth Science, 73, 87-94. DOI: 10.1016/j.jseaes.2013.04.014.

Khan, S., Cao, Q., Zheng, Y.M., Huang, Y.Z. \& Zhu Y.G. (2008). Health risks of heavy metals in contaminated soils and food crops irrigated with wastewater in Beijing, China. Environ. Pollut., 152, 686-692. DOI: 10.1016/j. envpol.2007.06.056.

Komárek, M., Vaněk, A. \& Ettler V., (2013). Chemical stabilization of metals and arsenic in contaminated soils using oxides. Environ. Pollut., 172, 9-22. DOI: 10.1016/j.envpol.2012.07.045.

Lee, C.S.L., Li, X., Shi, W., Cheung, S.C. \& Thornton I. (2006). Metal contamination in urban suburban, and country park soils of Hong Kong: a study based on GIS and multivariate statistics. Sci. Total Environ., 356, 45-61. DOI: 10.1016/j.scitotenv.2005.03.024.

Li, P., Lin, C., Cheng, H., Duan, X. \& Lei K. (2015). Contamination and health risks of soil heavy metals around a lead/ zinc smelter in southwestern China. Ecotoxicol. Environ. Saf., 113, 391-399. DOI: 10.1016/j.ecoenv.2014.12.025.

Lu, C.A., Zhang, J.F., Jiang, H.M., Yang, J.C., Zhang, J.T., Wang, J.Z. \& Shan H.X. (2010). Assessment of soil contamination with $\mathrm{Cd}, \mathrm{Pb}$ and $\mathrm{Zn}$ and source identification in the area around the Huludao Zinc Plant. J. Hazard. Mater., 182, 743-748. DOI: 10.1016/j.jhazmat.2010.06.097.

Lu, X.W., Zhang, X.L., Li, L.Y. \& Chen H. (2014). Assessment of metals pollution and health risk in dust from nursery schools in Xi'an, China. Environ. Res., 128, 27-34. DOI: 10.1016/j.envres.2013.11.007. 
Luo, C., Yang, R., Wang, Y., Li, J., Zhang, G. \& Li X. (2012a). Influence of agricultural practice on trace metals in soils and vegetation in the water conservation area along the East River (Dong jiang River), South China. Sci. Total Environ., 431, 26-32. DOI: 10.1016/j.scitotenv.2012.05.027.

Luo, W., Lu, Y., Giesy, J.P., Wang, T., Shi, Y., Wang, G. \& Xing Y. (2007). Effects of land use on concentrations of metals in surface soils and ecological risk around Guanting reservoir, China. Environ. Geochem. Health, 29, 459-471. DOI:10.1007/s10653-007-9115-z

Luo, X.S., Yu, S. \& Li X.D. (2012b). The mobility, bioavailability, and human bioaccessibility of trace metals in urban soils of Hong Kong. Applied Geochemistry, 27, 995-1004. DOI: 10.1016/j.apgeochem.2011.07.001.

Ma, X., Zuo, H., Tian, M., Zhang, L., Meng, J., Zhou, X., Min, N., Chang, X. \& Liu L. (2016). Assessment of heavy metals contamination in sediments from three adjacent regions of the Yellow River using metal chemical fractions and multivariate analysis techniques. Chemosphere, 144, 264-272. DOI: 10.1016/j.chemosphere.2015.08.026.

Maanan, M., Saddik, M., Maanan, M., Chaibi, M., Assobhei, O. \& Zourarah B. (2014). Environmental and ecological risk assessment of heavy metals in sediments of Nador lagoon, Morocco. Ecological Indicators, 48, 616-626. DOI: $10.1016 /$ j.ecolind.2014.09.034.

Muller, G. (1969). Index of geoaccumulation in sediments of the Rhine River. Geophysical Journal of the Royal Astronomical Society, 2(3), 108-118.

NEN 5704 (1996). Soil-sample preparation of soil-extraction with a calcium chloride solution $(0.01 \mathrm{~mol} / \mathrm{L})$.

Nemerow, N.L. (1985). Stream, lake, estuary, and ocean pollution. New York: Van Nostrand Reinhold Publishing Co.

Nouri, M., Gonçalves, F., Sousa, J.P., Römbke, J., Ksibi, M., Pereira, R. \& Haddioui A. (2013). Metal uptake by spontaneous vegetation in an abandoned iron mine from a Semiarid area in Center Morocco: Implications for phytoextraction. Environmental Research, Engineering and Management, 64, 59-71. DOI: 10.5755/j01. erem.64.2.3866.

Nouri, M., Gonçalves, F., Sousa, J.P., Römbke, J., Ksibi, M., Pereira, R. \& Haddioui A. (2014). Metal concentrations and metal mobility in Ait Ammar Moroccan mining site. Journal of Materials Environmental Science, 5(1), 271-280. http://www.jmaterenvironsci.com

Pastor, J. \& Hernandez A.J. (2012). Heavy metals salts and organic residues in old solid urban waste landfills and surface waters in their discharge areas: determinants for restoring their impact. J. Environ. Manag., 95(Suppl.), S42-S49. DOI: 10.1016/j.jenvman.2011.06.048.

Pejman, A., Bidhendi, G.N., Ardestani, M., Saeedi, M. \& Baghvan A. (2015). A new index for assessing heavy metals contamination in sediments: A case study. Ecological Indicators, 58, 365-373. DOI: 10.1016/j.ecolind.2015.06.012.

Posthuma, L., Eijsackers, H.J.P., Koelmans, A.A. \& Vijver M.G. (2008). Ecological effects of diffuse mixed pollution are site-specific and require higher-tier risk assessment to improve site management decisions: A discussion paper. Sci. Total Environ., 406, 503-517. DOI: 10.1016/j.scitotenv.2008.06.065.

Reddy, K.R. \& DeLaune R.D. (2004). Biogeochemistry of Wetlands: Science and applications. Boca Raton: CRC Press.

Scazzola, R., Avezzu, S., Biancotto, R., Chiamenti, E., Chiozzotto, E., Gerotto, M., Palonta, M. \& Roiter S. (2003). Assessment of heavy metal background values in the soils of inland coastal areas of Venice, Italy. Ann. Chim., 93, 465-470.

Stafilov, T., Šajn, R., Pančevski, Z., Boev, B., Frontasyeva, M.V. \& Strelkova L.P. (2010). Heavy metal contamination of topsoils around a lead and zinc smelter in the Republic of Macedonia. J. Hazard. Mater., 175, 896-914. DOI: 10.1016/j.jhazmat.2009.10.094.

Taylor, S.R. \& McLennan S.M. (1995). The geochemical evolution of the continental crust. Rev. Geophys., 33, 241-265. DOI: 10.1029/95RG00262.

Tomlinson, D.L., Wilson, J.G., Harris, C.R. \& Jeffrey D.W. (1980). Problems in the assessment of heavy-metal levels in estuaries and the formation of a pollution index. Helgol. Meeresunter., 33, 566-575. DOI: 10.1007/BF02414780.

Van Hullebusch, E.D., Lens, P.N.L. \& Tabak H.H. (2005). Developments in bioremediation of soils and sediments polluted with metals and Radionuclides. 3. Influence of chemical speciation and bioavailability on contaminants Immobilization/Mobilization bio-processes. Reviews in Environmental Science and Biotechnology, 4, 185-212. DOI: 10.1007/s11157-005-2948-y.

Walkley, A. \& Black I.A. (1934). An examination of Degtjareff method for determining organic carbon in soils: effect of variations in digestion conditions and of inorganic soil constituents. Soil Sciences, 63, 251-263. DOI: 10.1097/00010694-194704000-00001.

Wang, Q., Xie, Z. \& Li F. (2015). Using ensemble models to identify and apportion heavy metal pollution sources in agricultural soils on a local scale. Environ. Pollut., 206, 227-235. DOI: 10.1016/j.envpol.2015.06.040. 
Wen, H., Zhang, Y., Cloquet, C., Zhu, C., Fan, H. \& Luo C. (2015). Tracing sources of pollution in soils from the Jinding $\mathrm{Pb}-\mathrm{Zn}$ mining district in China using cadmium and lead isotopes, Applied Geochemistry, 52, 147-154. DOI: 10.1016/j.apgeochem.2014.11.025.

Wu, S., Xia, X.H., Lin, C.Y., Chen, X. \& Zhou C.H. (2010). Levels of arsenic and heavy metals in the rural soils of Beijing and their changes over the last two decades (1985-2008). J. Hazard. Mater., 179, 860-868. DOI: 10.1016/j. jhazmat.2010.03.084.

Wu, S., Peng, S., Zhang, X., Wu, D., Luo, W., Zhang, T., Zhou, S., Yang, G., Wan, H. \& Wu L. (2014). Levels and health risk assessments of heavy metals in urban soils in Dongguan, China. Journal of Geochemical Exploration, 148, 71-78. DOI: 10.1016/j.gexplo.2014.08.009.

Zhang, J. \& Liu C.L. (2000). Riverine composition and estuarine geochemistry of particulate metals in Chinaweathering features, anthropogenic impact and chemical fluxes. Estuar. Coast. Shelf Sci., 54, 1051-1070. DOI: 10.1006/ecss.2001.0879.

Zhang, C., Qiao, Q., Piper, J.D. \& Huang B. (2011). Assessment of heavy metal pollution from a Fe-smelting plant in urban river sediments using environ-mental magnetic and geochemical methods. Environ. Pollut., 159, 3057-3070. DOI: 10.1016/j.envpol.2011.04.006.

Zhang, H., Liu, G., Shi, W. \& Li J. (2014). Soil heavy metal contamination and risk assessment around the Fenhe Reservoir, China. Bull. Environ. Contam. Toxicol., 93, 182-186. DOI: 10.1007/s00128-014-1304-8.

Zhou, P., Zhao, Y., Zhao, Z. \& Chai T. (2015). Source mapping and determining of soil contamination by heavy metals using statistical analysis, artificial neural network, and adaptive genetic algorithm. Journal of Environmental Chemical Engineering, 3(4A), 2569-2579. DOI: 10.1016/j.jece.2015.08.003. 